\title{
Reading Philemon as therapeutic narrative
}

Authors:

Pierre J. Jordaan

S. Philip Nolte

\begin{abstract}
Affiliations:
${ }^{1}$ School of Biblical Studies and Bible Languages,

North-West University,

Potchefstroom campus,

South Africa
\end{abstract}

\section{Correspondence to:}

Pierre J. Jordaan

email:

pierre.jordaan@nwu.ac.za

\section{Postal address:}

Biblical Studies and

Bible Languages, Private

Bag X6001, North-West

University, Potchefstroom

campus, South Africa

\section{Keywords:}

Philemon; narrative

therapy; master-slave

relations; dominant

narrative; Paul

\section{Dates:}

Received: 06 July 2009

Accepted: 04 Nov. 2009

Published: 29 Mar. 2010

How to cite this article: Jordaan, P.J., Nolte, S.P., 2010, 'Reading Philemon as therapeutic narrative', HTS Teologiese Studies/ Theological Studies 66(1), Art. \#307, 6 pages. DOI: 10.4102/hts.v66i1.307

\section{This article is available} at:

http://www.hts.org.za

\section{Note:}

Prof. Pierre J. Jordaan is an associate professor of Greek at the School of Biblical Studies and Bible Languages in the Faculty of Theology at the Potchefstroom campus of North-West University. Dr S. Philip Nolte is a postdoctoral research fellow of Prof. Jordaan, conducting research into how embodied cognition theory affects and enriches the interpretation of apocryphal texts in the Septuagint.

\section{(c) 2010. The Authors.}

Licensee: OpenJournals

Publishing. This work

is licensed under the

Creative Commons

Attribution License.

\section{ABSTRACT}

This article analysed the different narratives implied in Philemon by utilising the narrative therapeutic approach, as developed by Epston and White (1990). A dominant narrative (the harsh treatment of slaves in the early Christian environment) and a challenging narrative (a more humane conduct of slaves) were clearly distinguished. The article showed Paul's attempt to bridge the gap between these two narratives by using certain pointers, possibly taken from mystery religions and Jesus' example. In conclusion, the narrative therapeutic approach proved to be a new and unique way of looking at Philemon's narrative world.

\section{INTRODUCTION}

\section{The problem}

In Rediscovering Paul: Philemon and the sociology of Paul's narrative world, Norman R. Petersen argues convincingly that narratives/stories can be construed from any of Paul's letters. Petersen (1985:9) states that 'in letters the form of discourse, of speaking to someone, subordinates the story and its narrative world to the presentation of the message.' Petersen uses three different criteria (narrative worlds, symbolic forms and social arrangements) to extract narratives from Philemon. By working in this way, Petersen shows various narratives in the letter to Philemon, namely that of Philemon, Onesimus and Paul. Building on Petersen's analysis, this article not only brings to light the different narratives within Paul's letter to Philemon, but also investigates the relationship between these narratives, by means of a literary application of the narrative therapeutic approach. Although this approach is essentially therapeutic, it has also proved to be a useful perspective from which to conduct a literary analysis, because it can highlight different dynamics in a text that were previously neglected. This method, as well as certain minor changes made to it to adapt it to a literary context, will be discussed later.

The reading of a text from this perspective makes that text more rewarding, because it allows for different interpretations of it. This becomes therapy in action. Indeed, the aim of narrative therapeutic reading is to highlight the problem, the improvement and the unavoidable change within a community. At a first glance, Philemon $^{1}$ seems to be just another story with a sad beginning and 'maybe' a good ending. Philemon, as most commentators interpret it, details a story of a runaway slave (Martin 1985) whose wronged master is asked by the Apostle Paul to not punish him, but to accept the slave back wholeheartedly. We do not know what the outcome of Paul's request was. There has, however, been wide speculation about what the possible outcome might have been (Petersen 1985). During this speculation, many other important questions were raised:

- What was the view on slaves in general?

- What did Onesimus in actual fact do wrong?

- Why was Paul so fervently petitioning for the acceptance of Onesimus?

- Why would Philemon indeed listen to Paul?

These are amongst some of the very interesting issues that call for deeper inquiry and interpretation. This investigation takes the stance that Philemon is a complex text and therefore does not opt for a simple, one-dimensional interpretation.

Many approaches have been followed in order to interpret the meaning of Philemon. ${ }^{2}$ This article employs a narrative therapeutic approach as pioneered by Epston and White (1990). In addition, it follows a diachronic approach. In other words, it constructs the historical setting using certain pre-set criteria. In contrast to other approaches, it works explicitly with two conflicting narratives. It shows how Paul might have used certain ideas/events from the past to create a new narrative. This article is unique in its line of approach in that it combines certain aspects of text analyses that were previously employed separately. These include aspects such as the identified ideological background, which might have been the patriarchal worldview (Barth \& Blanke 2000), the subservient, docile role of the slave body (Horsley 1998), and the movement between the two identified opposing narratives. Contrary to an initial impression, the narrative therapeutic approach does not emerge from a completely psychological angle. Psychological approaches, especially if they work with psychoanalysis/psychodynamics, seem to be speculative and defy rules of logic (Efthimiades-Keith 2004). However, the narrative therapeutic approach as used in at least three publications (Jordaan 2002, 2006, 2009), prefers to work on a literary level, with pre-set narrative criteria, rather than speculative psychoanalytical and psychodynamical criteria. Furthermore, a narrative therapeutic reading does not exist in a vacuum, therefore this investigation takes the research of scholarly predecessors into account and incorporates it in order to establish a detailed background to Philemon. Considering this background, a narrative therapeutic analysis follows by applying certain criteria to the text. Lastly, the article will demonstrate the results of this analysis, presenting a different picture from previous research as a result of applying this different set of analytical tools.

1.For the purpose of this paper, Philemon (italics) refers to the book and Philemon (without italics), to the person.

2.Larry Kreitzer (2008) gives a rather detailed overview of approaches to Philemon. He also deals with ways in which the content of the epistle was utilised in literature, as well as cinematographic versions thereof. 


\section{THEORETICAL AND METHODOLOGICAL FRAMEWORK}

None of the consulted commentaries viewed Philemon in terms of a master narrative and a challenging narrative. These terms, as well as other relevant concepts, and their place within the narrative therapeutic framework as used by Epston and White, will now be discussed.

\section{Some relevant terms of narrative therapy Story}

A story is told to make sense of a person's life. This means experiences and events are organised in such a way that people can make sense of the world around them (Epston \& White 1990) There are various stories to be told in Philemon. Petersen (1985:ix) shows that letters, such as Paul's letter to Philemon, 'have stories and that the events of these stories are re-emplotted [sic] in the composition of letters, usually with clear rhetorical significance. We can therefore assume that Paul, Philemon, Onesimus and Apphia each has their own stories. The letter itself is Paul's story about the relationships between himself, Philemon and Onesimus, as well as the possible conflict between Onesimus and Philemon. Paul's story also hints that Onesimus should be accepted by Philemon as a brother. The relevance of a narrative therapeutic approach to Philemon thus lies in the relevance of the characters' stories, even though those stories are formally and rhetorically structured as a letter. Naturally, the reason for writing the letter has its own story.

\section{Resistance}

The story sometimes seems to become disorganised as resistance is encountered. This resistance usually erupts as another story (master narrative) is forced on a person's life and a problemsaturated story is formed in this way. This problem-saturated story needs to be rewritten in a way that would restore sense to a person's life (Epston \& White 1990). Resistance in Philemon emerges when the slave, Onesimus, arrives at Paul, and is subsequently sent back to his master, Philemon. Resistance in this instance exists in the sense that Philemon and Onesimus find themselves simultaneously in two worlds: the one is their contextual world/history (Petersen 1985), which refers to a world where master-slave relations are dominant and where Philemon is in a position to punish Onesimus; the other is the narrative world/referential history (Petersen 1985) of the letter - the world of the faith community where alternative relations come into play. This narrative world created by Paul could lead to resistance from Philemon.

\section{Dominant narrative}

The dominant narrative presents the established and accepted story of a community or a person's life. Such narratives shape and structure societies, eventually becoming dominant ideologies that are, in turn, maintained by these dominant/ master narratives (see Adam 1995; Breytenbach 1997; Craffert 2002; Cunningham 2003; Lyotard 1984; Vanhoozer 2003). The social anthropologist, Clifford Geertz (1973:87-125), describes people's worlds as 'symbol systems'. These are combinations of symbols and language and serve as models for everyday life. Models function on two levels, namely as an expression of how life is structured and lived, as well as a blueprint for coming generations for how life should be lived in their own or other societies, such as the one represented in the accepted symbol system (Petersen 1985). These systems/narratives are powerful because they are accepted as truth and objective reality. T.O. Beidelman (1971), an anthropologist who also studies religion, shows that societies structure themselves in terms of shared ways of behaviour, which build upon ways in which people perceive themselves and the worlds they live in. People communicate these convictions through language, but Beidelman (1971:30) also says: 'by language I mean far more than grammar, syntax, and vocabulary. What I mean is the sum total of ways in which the members of a society symbolise or categorise their experience so that they may give it order and form and thereby manipulate it and also deal with their fellows who share this experience with them.' The dominant narratives are usually handed down from generation to generation and are thus largely unquestioned (Epston \& White 1990). Dominant narratives are ideologically immersed; however, they can usually be summed up in simple one-liners, for example 'masters are better than slaves', or 'apartheid is God-given'. The dominant narrative that serves as the background against which Philemon has been written is the master-slave relationship within the ancient Roman empire. This dominant narrative is countered by another, however, namely the alternative narrative.

\section{Alternative narrative}

The alternative narrative questions the power and knowledge of the dominant narrative (Epston \& White 1990). It is created to restore sense to a character's life. In this case, it is the narrative world of Philemon, aimed at defusing the possible conflict between Philemon and Onesimus, within the boundaries of the faith community. It is important to note that Philemon was not written to change the social reality of master-slave relations in their contextual world, but it can be speculated that, with this narrative, Paul is canvassing for a more humane society. A new set of shared behaviours needs to be constructed within the faith community to which Paul, Philemon and Onesimus belong. It must be stressed that alternative narratives can be expected to be met by resistance. It is therefore interesting to look at the rhetorical strategies which Paul employs to structure his letter to Philemon, in order to minimise the amount of possible resistance from Philemon's side.

\section{Body}

The human body usually constitutes the place where discrimination takes place. Bodies of slaves and women were regarded as inferior and 'docile' in ancient societies. It was believed that such a body should become a conscript and be submissive to the views of the dominant narrative. On the other hand, bodies of masters were regarded as superior. The view of the body is just a matter of what the objective reality defines it to be (Epston \& White 1990). In this context, the objective reality would be the prevalent view of the inferiority of slaves' bodies, which could not be disputed. This means that if you can understand how a community views a body, you can also understand much about how that body functions within a community. The view held in regard to slaves' bodies in ancient societies was part of the conviction that certain people did not have any value and could, therefore, easily be marginalised within their communities. Part of Paul's alternative narrative in Philemon is to challenge this view of people in the faith community, because when Paul urges Philemon to accept Onesimus as a brother, he uses language that constitutes a radically different community (that is, one which promotes kinship) to the one in which Philemon and Onesimus belong. Within this community of kinship, Onesimus can no longer be marginalised to the position of a 'nobody', but must be seen as someone with a changed status, namely as someone who forms part of the same family as Paul and Philemon, which is the family of God.

\section{Therapy}

This is the re-establishment of personal agency from the oppression of external problems and the dominant stories of larger systems (Corey 2005). Therapy occurs when the dominant narrative is effectively challenged by an alternative narrative; if the dominant narrative is not challenged and dealt with accordingly, there can be no therapy. In a way, therapy is realised in Philemon when Paul pleads with Philemon to accept Onesimus as a brother, thereby anticipating the possibility to create an egalitarian faith community.

\section{Problem}

Narrative therapy does not see a person as a problem, but a problem as a problem (Epston \& White 1990). This means that Philemon per se is not the problem, rather, the problem lies 
with the discriminating system in which he exists. Problems would therefore predominantly prevail in larger entities. For example, Sharon may be a good person; however, Sharon under the influence of drugs is not. If the problem is removed, the individual would function normally again. It is recognised that the discriminating system of master-slave relations was so contextually entrenched that it could not have been removed. Therefore, as long as Onesimus was a slave, he would have to face the reality of the system's oppressing rules. Paul, nonetheless, opposes this system and asks for a more compassionate faith community.

\section{Externalising the problem}

In order to address a problem, it should first be externalised placed outside a person (Epston \& White 1990) - as demonstrated above by focusing on the discriminatory system as the problem.

\section{Unique outcome}

One generates a unique outcome of a story by looking at ways in which similar problems have been handled in the past. Solutions generated in response to past problems provide the impetus and are illustrative of ways to handle existing and possible future problems (Epston \& White 1990). In a literary setting, this would mean seeking out similar circumstances in the past and applying the principles - underlying unique outcomes - to the problematic situation in the present. These unique outcomes are quite different from a counselling situation, where there is a oneon-one relationship between therapist and client.

\section{A storied therapy}

This begins with a story that has gone wrong due to a certain dominant narrative. Another challenging narrative emerges. A problem is identified and externalised. These problems are usually related to the bodies of certain people considered inferior versus others considered superior. A new story is then compiled, based on the unique outcomes in the past.

\section{Summary}

A narrative therapeutic reading of ancient texts tends to highlight interesting dynamics within the text. This should especially be the case in narrative Biblical texts (or even extra-biblical texts), as there usually is a story to be told of a dominant narrative that needs to be confronted, and in the process corrected by a challenging narrative. The term 'body' as used in narrative therapy reflects the ideological setting of the text. This, together with the way in which problems are defined, namely as lying outside a person, affects the distance between a person and a problem and therefore makes the problem more manageable. Unique outcomes tell us how similar problems have been dealt with in the past and point in the direction of how it should be managed in the present. The blending of all these elements results in a narrative therapeutic reading of a text.

The above description of the theory and method of narrative therapeutic reading will consequently be demonstrated by an examination of Philemon along the following lines:

- the construction of the story behind names - namely, what readers probably know about the characters

- analysis of these stories in terms of dominant and challenging narratives

- the externalising of a certain problem

- the formulation of unique outcomes

- the description of a storied therapy

- the findings of such a reading.

\section{CHARACTER STORIES IN PHILEMON}

The importance of letting characters tell their own stories in narrative therapy must be stressed. However, one also has to accept the problematic situation surrounding the ancient Greek narrative, where the narrator is often the voice that speaks for slaves, and presumably, other characters too. Therefore, what we have are not the characters' words, but the narrator speaking through those characters. This means that we have to construct the stories and characters from what the narrator gives us.

\section{The Apostle Paul}

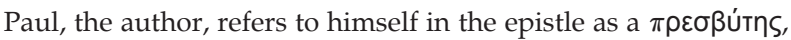

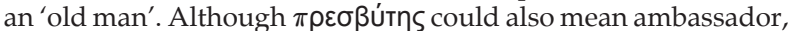
the literal meaning 'old' is taken here - as the letter to Philemon seems to be written fairly late in the corpus of genuine Pauline letters (see Burkett 2002) and Paul might have been aged already. Paul was originally a persecutor of Christians. On the road to Damascus, he had an experience that he considered a revelation or vision of the risen Jesus (Gal 1:15-17; 1 Cor 9:1; 15:8.). This socalled 'Damascus event' transformed him from a persecutor to a preacher and the first missionary of Christianity.

Furthermore, the encounter at Damascus decisively shaped Paul's theological thinking. According to Schnelle (2003), Paul reflects on this overwhelming experience in his letters, especially the significance of how God transformed Jesus from the realm of death to life. The goal of the transformation of Jesus Christ is the participation of believers in this fundamental event. Paul was the first person we know about to interpret Jesus' death and resurrection in terms of a believer's own: experiencing the death of a sinful, shameful life and being resurrected to a new, blameless life. Paul uses the allegorical and typological (Schnelle 2003) exegetical methods to explain his view on the death and resurrection of Christ. Paul's letter to the Galatians clarifies this interpretation by asserting that the Jewish law could not put the sinner in the right relationship with God (Gal 2:16). However, Christ put the sinner in the right relationship with God by dying on the cross. Paul goes on to extend this event to something that also occurs on a personal level, 'I have been put to death with Christ on his cross' (Gal 2:19). Paul then argues in Gal 2:20, 'so that it is no longer I who live but it is Christ who lives in me. This life I live now, I live by faith in the Son of God, who loved me and gave his life to me' (Good News Bible, Today's English Version). This is a typical allegorical and typological interpretation of Christ dying on the cross. It is allegorical in the sense that there is a deeper, almost hidden meaning, and typological in that the same 'type' of thing should happen to the believer. A believer also dies with Christ on the cross and is then resurrected to a new way of living. Thus, a transformation has to take place in each believer's life.

This rather dynamic change in a person's life is signified by a baptism. ${ }^{3}$ Baptism denotes being 'in Christ' (Schnelle 2003:481), for in Christ, a new status emerges. ${ }^{3}$ Paul describes this new status in Galatians 3:28, 'So there is no difference between Jews and Gentiles, between slaves and free people, between men and women; you are all one in union with Christ Jesus' (Good News Bible, Today's English Version). This dynamic, transformational ritual of death and resurrection to a new life is not typical of Judaism. Judaism has other rituals, such as circumcision and the bar mitzvah for boys at the age of twelve, but it never signifies death and resurrection (Neuser \& Avery-Peck 2003). However, a dying-rising god and related rituals are characteristic of GraecoRoman mystery cults (Price \& Kearns 2003). Another peculiarity of these cults is that on initiation, everyone was considered equal (Lohse 1986), as discussed above in relation to the baptism.

Paul must have taken over this idea from his environment, as the same religious themes are found in the mystery religions. However, he does not take it over unconditionally. Christ, instead of the deity, was put in the centre. Death and resurrection to a new life had to be with Christ. The same can be said of

3.In a recent $\mathrm{PhD}$ dissertation, called Baptism, eucharist, and the earliest Jesus-groups - from the perspective of alternate states of consciousness, Jonanda Groenewald (2006:169-236) describes baptism as initiation ritual into a new community, namely the 'family of God'. 
baptism as initiation ritual. If there was equality after baptism, it was because of the unity in Christ. Naturally, this would have resulted in tension among the believers, because it meant slaves subsequently be treated as equals.

Paul's theology was not only influenced by the ideas of mystery cults; he was also influenced by what he was told about Christ.

The gospels as we know them had not yet emerged by the time Paul had written the letter to Philemon. Where did Paul then get his facts on Christ, as he did not know Christ personally? One possibility might be the oral tradition concerning Christ. We know that Paul had contact with other disciples, such as Peter. Paul and Peter had conflicts over Peter's exclusion of nonJews at meals (Gal 2:11-14). Here again the tension erupts over inequality among the believers. This was unacceptable to Paul. It seems that the oral tradition concerning Christ's compassion and inclusiveness towards marginalised people particularly appealed to Paul. This was, however, not always the case in Paul's life. In his previous dispensation, he was a Pharisee and, as such, a proponent of the exclusivity of the Jewish religion, but in Christ everything had changed. In Philemon, Paul is introduced as a person, who, like Jesus, has a compassionate heart towards the marginalised. In this case his compassion extends towards the slave, Onesimus. This becomes evident from the following:

- Onesimus has become his own son. Paul states: 'I have

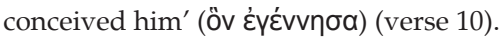

- Onesimus is no longer 'useless' (äxрпотоv), but 'useful' (घüxрпणтоv) (verse 12).

- Paul's 'heart' ( $\sigma \pi \lambda a ́ y X v a)$ goes with him (verse 12).

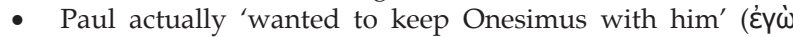

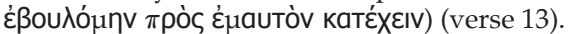

- Onesimus should be received 'not as a slave, but more than

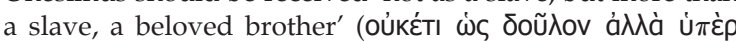

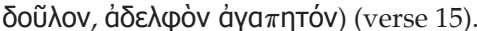

- Philemon 'should receive Onesimus as he would himself'

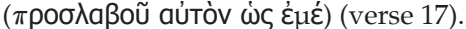

- If Onesimus had taken something, Paul 'himself shall pay'

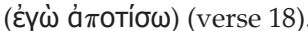

Considering the above, one can make the deduction that Paul genuinely had compassion towards the slave Onesimus, valuing him as a person. It is important to note that this high value pertains to Onesimus' body as well. Paul openly suggests that Onesimus should have an amicable reconciliation with Philemon. He does not address the issue of corporeal punishment, but is certainly not advocating it. Paul does not regard Onesimus as just another slave with a disposable, docile body; rather, he sees Onesimus as a valuable individual who deserves to be taken back with the minimum consequences. This compassion toward the marginalised is also a characteristic of Jesus.

Further on in Paul's story, Paul also emerges as patron of both Onesimus and Philemon (clients), who came to faith in Jesus Christ through him. The patron-client relationship is a reciprocal one, where the patron gives homage and guidance to the client, while the client replies with the necessary respect towards the patron (Martin 1990). The story of Paul becomes complicated, as he is a patron of both Philemon and Onesimus. If he had pleased one, it would have meant shaming the other. How would Paul handle this tricky situation? The answer is that Paul uses his profound skill as a rhetorician to persuade Philemon to accept Onesimus back, using rhetorical devices like dramatic intrigue (Barth \& Blanke 2000). His whole approach to Philemon is voluntaristic, allowing him to settle the matter by an appeal to Philemon's conscience (Martin 1990).

In short, Paul's story is one of transformation. The story of complete reversal/alteration of direction, that is, from walking in one direction and, after a transformative experience, taking a wholly new direction; a story of campaigning for the Pharisees, to using all the means at his disposal to expand the gospel of Jesus Christ. He changed from having an exclusive message to having an inclusive message, from fighting for inequality to promoting greater equality, from witnessing killings of believers to preserving lives of believers, from a persecutor to a compassionate patron.

\section{Philemon the slave owner}

Philemon emerges as an influential person. He is not just a house-owner but also the owner of the slave Onesimus. He is the paterfamilias with wife, children and slaves. Since having converted to Christianity, Philemon supported other believers in various ways, including placing his house at the disposal of Christians. Paul paints him with rhetorical eloquence as a true benefactor:

- 'the hearts of the believers was refreshed by your brother'

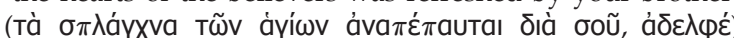
(verse 7)

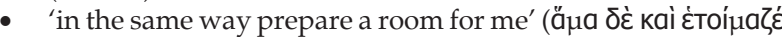
$\mu$ o ६Evíav) (verse 22).

However, the presence of his slave in the company of Paul proves to be a problem. Onesimus wronged Philemon in some way and commentators have speculated widely about the nature of this offence. It could have been stealing (Lightfoot 1987), slandering his master (Martin 1985), or even plainly overstaying his welcome with Paul. Whatever the situation might have been Philemon could have felt justified in seeking retribution or considering retaliation. Owners had limitless authority over their slaves, which meant that they could punish them in any way and could even kill them, if they thought it was necessary. Philemon had the authority to consider severe physical punishment for Onesimus because of his transgression (Glancy 2002), which could include forcing Onesimus to receive a permanent tattoo or even a slave collar. Harsh treatment might even be the very reason why Onesimus ran off in the first place and met with Paul, slandering his master for committing cruelties against him. Horsley (1998) suggests the slave-owners were the main culprits committing atrocities against subordinates. This is, however, pure speculation, as no substantial evidence exists.

What can be said is that Paul is notably petitioning Philemon for a more compassionate approach towards non-equals. Providing hospitality to a person of higher standing is noble; giving out your house for worship to equals is quite commendable, but forgiving, accepting and even showing compassion to a slave, is far better. Paul expected this from Philemon. By meeting Paul's expectation of him, Philemon would be acting in accordance with the teachings of Jesus: he would show compassion to the down-trodden and the marginalised of society. Philemon would then also honour his patron, Paul, by doing so. This would settle the score between them and sufficiently prove that Philemon is not just a nominal, comfortable believer, but is indeed taking his beliefs a step further. Thus, Philemon found himself under increasing pressure to provide a solution and turn this problemsaturated story around.

\section{Onesimus the slave}

The sections above, concerning the Apostle Paul and Philemon the slave owner, already reveal much about Onesimus. He is with Paul for some unknown reason, who is totally convinced of Onesimus' sincerity in Christ. Paul says the following about Onesimus:

- 'he would be able to minister to Paul on behalf of Philemon'

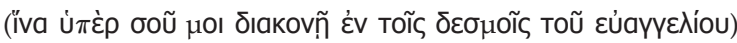
(verse 13)

- 'he was only separated for a short while from you in order that you may have him for always' (Táxa yàp סıà ToũTo

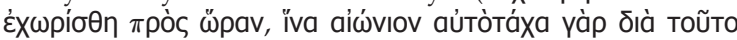

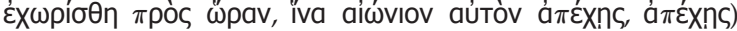
(verse 16)

- 'If he has wronged in a way or owes you, put it on my account, I Paul write with my own hand, I will pay' ( $\varepsilon$ i $\delta \varepsilon$

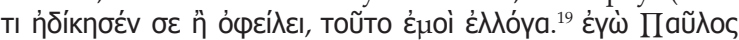

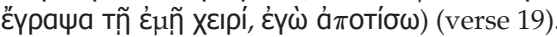


In this correspondence from Paul to Philemon, Onesimus becomes the object of the discord. This (over)statement of Onesimus' virtues and Paul's willingness to compensate for any suffered losses, suggest that Onesimus is in serious trouble. As has been established, Paul is campaigning for a compassionate reception of Onesimus. Could it be the omission of bodily punishment? In this regard, we unfortunately do not know Philemon's point of view or attitude.

\section{Other characters}

There are a few other characters in Philemon who play minor roles in the narrative, including Apphia and Archippos. These characters are not insignificant as such, but they do not play an important role as far as the purpose of this article is concerned.

\section{THE DOMINANT AND ALTERNATIVE NARRATIVES}

The dominant narrative usually represents ideology and the treatment of docile bodies. The challenging or alternative narrative represents how the dominant narrative is challenged, and eventually, triumphed over. These different narratives consequently receive attention.

\section{The dominant narrative}

All the narratives show that early Christians might have had high ideals, but they were difficult to accomplish. Contrary to popular belief, everything was not 'signed, sealed and delivered' (revealed). Early Christianity struggled for ages with various social issues, one of them being slavery. A major concern might have been the treatment of slaves that came to faith in Jesus Christ. This was all the more the case if they had transgressed, as Onesimus had presumably done, and this presented a peculiar dilemma for slave-owners such as Philemon. They had every right to harm or even kill a slave; however, Paul asks for leniency towards Onesimus. This must have created a moral dilemma for Philemon. Naturally, it was easier to treat people of higher class and even from the same class as equals, but accepting a slave that had done something wrong as a brother, really posed a challenge. Philemon was confronted by such a situation while it was within his rights to retaliate and even claim compensation for losses suffered. The evident course of action was to punish the slave, as well as his benefactor, and claim compensation for the time that Onesimus was absent.

\section{The alternative narrative}

The alternative narrative challenges the dominant narrative. The guidelines for the alternative narrative were set by Christ himself, who had compassion for the marginalised in the community, including women, children and tax collectors. Paul himself propagated equality in Christ, with texts like Galatians 3:28. 'In Christ' everybody was equal, even slaves and free men. Paul now urges Philemon to accept Onesimus as 'more than a slave' and 'like a beloved brother'. This is quite contrary to the fact that Onesimus probably deserved severe corporeal punishment for his transgression. Paul asked Philemon to act with compassion, based on the fact that he was a patron to Philemon. Philemon was indebted to Paul for bringing him into the faith. Philemon now had to prove that his faith was more than skin deep and something that he could use as a guide in dealing with complex, real-life issues which confronted him and thus show that the risen Christ is living in him. This places the ball solely in Philemon's court, so to speak, even though the narrative is subtle and open-ended, inviting the readers to draw their own conclusions from it.

\section{Externalising the problem}

The existent system discriminated against slaves, leaving them to the mercy of their owners. Anything could happen when they were accused of a transgression because slaves were powerless to improve their situation.
An externalisation of the problem might be formulated as 'the harsh treatment of slaves by their owners', or 'the regulating of slave bodies in an oppressive way'. Both of these statements have almost the same meaning, but with different focuses. For the purpose of this discussion, the first seems to be more inclusive and will therefore be the selected formulation for this study.

\section{UNIQUE OUTCOMES}

The unique outcome for 'the harsh treatment of slaves by their owners' had to be addressed in a creative way. The Jesus logia must have provided some guidelines - what did Jesus do and how did he respond to the plight of the marginalised? Jesus had an inclusive approach, pulling the marginalised towards the centre. The stories of Jesus' compassion towards women, children and tax collectors, exemplified his attitude towards the marginalised. ${ }^{4}$ Paul followed the example of Jesus. After his conversion to Christ, he adopted an inclusive attitude towards outsiders, even to the point of conflict with Peter. Furthermore, Paul's own previous writings also moved towards equality, more specifically Galatians 3:28. Here it states that 'in Christ' everybody was equal. We are aware of the problems that may arise when we use other texts to assist us in historical constructions, as well as constructions of narrative worlds. However, as Petersen (1985:14) points out, 'we can construct not only the narrative worlds of each of them [Paul's letters], but also the narrative world referred to in all of them. That is the world I refer to when speaking of Paul's narrative world.' Therefore, we use references from other letters of Paul as well to reflect on the way in which Paul was thinking and arguing about the relationships between slaves and their masters in the faith community. Andries van Aarde (2001:165-166, 178-179) indicates that:

- Paul uses the metaphor 'adopted as children' in Romans $8: 15,23 ; 9: 4$ and Galatians $4: 5$ to reflect on the relations between people in the new faith community (165).

- The above mentioned metaphor 'is not merely one of a number of widely recurring motifs related to the way Christians see themselves in the New Testament; indeed, it may be called a "root metaphor"' (177).

- Paul uses the metaphor 'inheritance' in Galatians in order to show that when people are in Christ, they are the spiritual 'sons of Abraham', the children of God (165).

From this it follows that the faith community forms a new, fictional family, in which people are brothers of whom Christ is the 'first of many brothers' (Rom 8:29). Various relationships are at work within this family, other than those experienced in everyday life. Paul also utilised the 'patron and client relationship scheme' to ensure a more human reception of Onesimus. All three of these provided the impetus for addressing the problem of the harsh treatment of slaves by their owners.

\section{A storied therapy}

The problem-saturated story is one of the harsh treatment of slaves and the general disregard for their bodies. Compassionate treatment of slaves might have been unthinkable. The fact that a slave might be converted to the Lord Jesus really posed a great challenge to early Christianity. What should be done with such a slave, if he transgressed? Can he still be punished severely, cursed and discriminated against? This is the dominant narrative that needed to be challenged. Paul took the initiative by proposing a more equal society. The storied therapy lies in the fact that the chains of bondage from an unjust system had to be shaken off and a new, more lenient narrative created.

\section{CONCLUSION}

The narrative therapeutic reading of Philemon posed exciting possibilities. Opposing narratives - the dominant and alternative - emerged. The analysis showed, on the one hand, how there was

4.See Andries van Aarde (2001) and Marcus J. Borg (1984). 
harsh treatment of slaves by their owners in an oppressive society and, on the other hand, how this was challenged. It proceeded to identify outcomes from the past and to externalise the problems that emerged. This approach indicated that sometimes a problem is created within a society and is not necessarily a problem per se. It might have been that slave-owners eventually overcame their moral challenges in this regard. In the end, we can say that therapy has taken place, in that there is movement from a problem-saturated story (the possible conflict between Philemon and Onesimus) to a solution-saturated story (Paul's request that Philemon is obliged to accept Onesimus as a brother).

\section{REFERENCES}

Adam, A.K.M., 1995, What is postmodern biblical criticism? Fortress, Minneapolis.

Barth, M. \& Blanke, H., 2000, The letter to Philemon: A new translation with notes and commentary. William B. Eerdmans Publishing Company, Grand Rapids.

Beidelman, T.O., 1971, The Kaguru: A matrilineal people of East Africa, Holt, Rinehart and Winston, New York.

Borg, M.J., 1984, Conflict, holiness and politics in the teachings of Jesus, Trinity Press International, Harrisburg.

Breytenbach, A.P.B., 1997, 'Meesternarratiewe, kontranarratiewe en kanonisering: 'n Perspektief op sommige profetiese geskrifte [Master narratives, contra-narratives, and canonization: A perspective on prophetic literature]', HTS Teologiese Studies/ Theological Studies 53(4), 1157-1186.

Burkett, D., 2002, An introduction to the New Testament and the origins of Christianity, Cambridge University Press, Cambridge.

Corey, G., 2005, Theory and practice of counselling and psychotherapy, Thompson Brooks/Cole, Belmont.

Craffert, P., 2003, 'Die nuwe hervorming - wat, waaroor, waarheen? [The new reformation - what is it about, and which road is it taking?]', in P. Muller (ed.), Die nuwe hervorming, pp. 67-87, Protea Boekhuis, Pretoria.

Cunningham, D.S., 2003, 'The Trinity', in K.J. Vanhoozer (ed.), The Cambridge companion to postmodern theology, pp. 186-202, Cambridge University Press, Cambridge.

Efthimiades-Keith, H., 2004, A Jungian psychoanalytic approach to the book of Judith, Brill Academic Publishers, Boston.

Epston, D. \& White, M., 1990, Narrative means to therapeutic ends, W.W. Norton \& Company, New York.
Geertz, C., 1973, The interpretation of cultures, Basic Books, New York.

Glancy, J.A., 2002, Slavery in early Christianity, Oxford University Press, New York.

Horsley, R.A., 1998, 'The slave systems of classical antiquity and their reluctant recognition by modern scholars', Semeia $83 \& 84,19-66$.

Jordaan, P.J., 2002, 'Colossians 4:7-18 as narrative therapy', Ekklesiastikos Pharos 81\&82, 47-62.

Jordaan, P.J., 2006, 'An interdisciplinary approach: Reading Ruth as therapeutic narrative', Theologia Viatorum 30(1), $1-24$

Jordaan, P.J., 2009, 'Reading Judith as therapeutic narrative', in J. Cook (ed.), Septuagint and reception, pp. 335-346, Brill, Leiden.

Kreitzer, L.J., 2008, Philemon, Sheffield Phoenix Press, University of Sheffield.

Lightfoot, J.B., 1987, St. Paul's epistle to the Colossians and Philemon, Hendrickson Publishers, Peabody.

Lohse, E., 1986, Colossians and Philemon, Fortress Press, Philadelphia.

Lyotard, J.-F., 1984, The postmodern condition: A report on knowledge, transl. University of Minnesota, Manchester University Press, Manchester.

Martin, D.B., 1990, Slavery as salvation: The metaphor of slavery in Pauline Christianity, Yale University Press, New Haven.

Martin, R.P., 1985, Colossians and Philemon, William. B. Eerdmans Publishing Company, Grand Rapids.

Neuser, J. \& Avery-Peck, A.J., 2003, The Blackwell companion to Judaism, Blackwell Publishing, Oxford.

Petersen, N.R., 1985, Rediscovering Paul: Philemon and the sociology of Paul's narrative world, Fortress Press, Philadelphia.

Price, S. \& Kearns, E. (eds.), 2003, The Oxford dictionary of classical myth and religion, Oxford University Press, Oxford.

Schnelle, U., 2003, Apostle Paul: His life and theology, Baker Academic, Grand Rapids.

Van Aarde, A., 2001, Fatherless in Galilee: Jesus as child of God, Trinity Press International, Harrisburg.

Vanhoozer, K.J., 2003, 'Theology and the condition of postmodernity: A report on knowledge (of God)', in K.J. Vanhoozer (ed.), The Cambridge companion to postmodern theology, pp. 3-25, Cambridge University Press, Cambridge. 